\title{
Epidemiology of malaria in the Amazon basin of Ecuador
}

\author{
Miguel San Sebastián, ${ }^{1}$ Ricardo Játiva, ${ }^{2}$ and Isabel Goicolea ${ }^{1}$
}

\begin{abstract}
Malaria is reemerging in most endemic countries of South America. In Ecuador, malaria is endemic on the Pacific coast, in the inter-Andean valleys, and in the Amazon River basin. In the Lower-Napo region of northeastern Ecuador, malaria was considered eliminated in the 1970s, but the disease has reemerged in recent years. Three organizations are involved in malariarelated work in the area, but they are not coordinating their efforts. This study was designed to describe the epidemiology of malaria incidence in the Lower-Napo region for the period of January 1992 through December 1995, and to determine the extent of seasonality in transmission in the area.

To determine malaria incidence, data were collected for that 4-year period from the records of the three malaria-related organizations: the office of the National Center for Malaria Eradication (NCME) in the town of Coca, the district hospital in Nuevo Rocafuerte (DHNR), and an association of community health workers called Sandi Yura. Data on climatic conditions for the same period were collected from the Ecuadorian Air Force and civil aviation authorities.

During the 1992-1995 period, NCME diagnosed a total of 773 malaria cases, DHNR diagnosed 485, and Sandi Yura clinically diagnosed 859. For the 4-year period, an annual parasite index of 40.4 was found with the DHNR data, 35.8 with the Sandi Yura data, and 6.2 with the NCME data. The predominant parasite in the area was Plasmodium vivax $(92 \%$ of all the cases). Twenty-eight percent of the infected persons were under 10 years old. No discernible differences between the genders were found. There was also no seasonal variation among the cases.

Further research is needed in order to confirm these findings and better understand malaria transmission in the region. The study highlights the need for a closer coordination among the area's malaria-control organizations so as to have an improved understanding of malaria epidemiology and to design and implement effective control strategies.
\end{abstract}

Malaria is reemerging in most endemic countries of South America. It has been suggested recently that among the reasons for this increase are

\footnotetext{
${ }^{1}$ Instituto de Epidemiología y Salud Comunitaria "Manuel Amunárriz," Coca, Ecuador. Send correspondence to: Miguel San Sebastián, Instituto de Epidemiología y Salud Comunitaria "Manuel Amunárriz," Apdo. 17-10-7410, Nicolás López 349 y Avenida La Prensa, Quito, Ecuador. Telephone: (02) 257689; fax: (02) 449763; e-mail: admin@mmcoca. ecuanex.net.ec

${ }^{2}$ Hospital Franklin Tello, Nuevo Rocafuerte, Napo, Ecuador.
}

a progressive deemphasis on vector control (DDT spraying) and a greater emphasis on case detection and treatment (1).

Malaria is one of Ecuador's major public health problems. The disease is endemic in three areas of the country: the Pacific coast of western Ecuador, the inter-Andean valleys of central Ecuador, and the Amazon River basin of eastern Ecuador. Sixty to eighty percent of the population exposed to malaria live in rural areas where dis- tance and a lack of transportation limit their access to health services (2).

The national malaria control program in Ecuador applies a vertical approach. The program is primarily carried out by the National Center for Malaria Eradication (NCME), which uses a control strategy based on DDT spraying, passive case detection, and presumptive treatment through voluntary collaboration at the community level.

In the Lower-Napo region of northeastern Ecuador, malaria was consid- 
ered eliminated in the 1970s, mainly due to a well-structured program of the NCME. However, several factors have led to a reemergence of malaria in the area. These include intrusion into the tropical forest by oil companies, uncontrolled colonization through a network of new roads, and an economic crisis in the country (3).

Malaria in the Lower-Napo region has shown a hypoendemic pattern of transmission. Plasmodium vivax is responsible for most of the cases. Although $P$. falciparum is on the increase, severe cases are uncommon (4). The vector species known in the area are Anopheles rangeli, A. nuneztovari, A. noroestensis, A. oswaldoi, and A. trinkae (5).

One of the recommendations of the Global Malaria Control Strategy of the World Health Organization is to adapt malaria control to the epidemiological, ecological, and socioeconomic characteristics of each area of a country (6). In these circumstances, an adequate knowledge of local malaria epidemiology is a key factor for appropriate resource allocation for effective malaria control.

This study was designed to: 1) describe the epidemiology of malaria incidence in the Lower-Napo region in the 1992-1995 period and 2) determine the degree of seasonality of transmission in the area.

\section{MATERIALS AND METHODS}

\section{Study area and population}

The Lower-Napo region is located in the north of the Ecuadorian Amazon. The Napo River, Ecuador's largest river and one of the main tributaries of the Amazon River, crosses the region from the west to the east. Located in the cantons (districts) of Francisco de Orellana, Sachas, and Aguarico, the Lower-Napo region covers an area of approximately $20000 \mathrm{~km}^{2}$. (At the time of the study, the region was located in Napo province; following a division of the province in 1998 , the region is now in the newly created province of Orellana.)

The region's population numbers approximately 40000 , of whom about
12000 are of the indigenous Napo Runa ethnic group and 2000 belong to the Shuar and Huaorani ethnic groups. The remaining 26000 inhabitants are more recent immigrants from the country's Pacific coastal and central highland regions. Approximately onethird of the region's population lives in small villages, where trading and oilindustry-related services are the main activities. The rest of the residents live scattered in the rain forest, where subsistence farming is the basis of the economy.

Three institutions working in malaria-related activities serve the region's 40000 residents: 1) the NCME, whose center in the town of Coca (also called Puerto Francisco de Orellana) has a catchment area of about 31000 people, 2) the district hospital in Nuevo Rocafuerte (DHNR), a town located some $300 \mathrm{~km}$ down the Napo River from Coca, serving a population of 3000 , and 3) an association of community health workers (CHWs) named Sandi Yura, which serves an indigenous population of approximately 6000 along the Napo River. Though the NCME is supposed to provide vector control services to all the region, the DHNR and the CHWs association do not receive support from NCME, mainly because of a lack of resources.

The climate in the Lower-Napo region is characteristic of a tropical rain forest. There is a high rainy season from March to July (monthly rainfall mean of $294 \mathrm{~mm}$, temperature mean of $26.3^{\circ} \mathrm{C}$ ) and a low rainy season from November to February (monthly rainfall mean of $168 \mathrm{~mm}$, temperature mean of $27.4{ }^{\circ} \mathrm{C}$ ). A humidity level of $80 \%$ is constant throughout the year (7).

\section{Data collection}

To determine malaria incidence, data were collected from the NCME in Coca, the DHNR, and the Sandi Yura association records for the 4-year period of January 1992 through December 1995. Cases from the NCME and the DHNR consisted of parasitological examinations of passive cases, while the Sandi Yura cases were based on clinical records without parasitological confirmation.

Data on climatic conditions for the 1992-1995 period were collected from the Ecuadorian Air Force in Quito and Tiputini and the Civil Aviation Center in Nuevo Rocafuerte.

\section{Data analysis}

Data collected from the different sources were examined and analyzed using Epi Info 6 statistical software (U.S. Centers for Disease Control and Prevention, Atlanta, Georgia, United States of America). Malaria incidence was determined by the annual parasite index (API), that is, the number of malaria cases per 1000 inhabitants per year. Mean rainfall, temperature, and number of malaria cases during each month of observation were calculated. In order to assess the degree of association between the monthly incidence of malaria and each of the climatic variables investigated, a linear regression model was applied and a correlation coefficient was computed.

\section{RESULTS}

\section{Malaria epidemiology}

For the 1992-1995 period, data collected from NCME showed an incidence of 773 malaria cases, the DHNR diagnosed 485 cases, and Sandi Yura clinically diagnosed 859 cases.

The NCME data reflected a relatively stable incidence of malaria cases over the 4 years, with a slight decrease in 1995; the annual mean was 193 cases. The DHNR data varied much more, with 90 cases in 1992, 40 in 1993, 127 in 1994, and a peak of 228 in 1995. Sandi Yura records showed constant levels during 1992-1994 (mean of 240 cases), with a decrease to 137 in 1995.

There were major differences in the APIs observed by NCME and the two other organizations for the 1992-1995 period. The NCME data showed an API of just 6.2, compared with a Sandi Yura API of 35.8 and a DHNR API of 40.4 . 
The main parasite in the area was $P$. vivax, causing $92 \%$ of all parasitic cases, according to the data from NCME and DHNR (the Sandi Yura health workers did not collect data on specific parasites). NCME data showed a modest decrease in $P$. falciparum infections during the 1992-1994 period, and then a much larger decline in 1995. However, the DHNR data showed the opposite pattern, with many more $P$. falciparum cases in 1994 and 1995 than there had been in 1992 and 1993 (Table 1).

There was a noticeable number of malaria cases among the youngest persons in the region. Of the cases diagnosed by the DHNR, 28\% were among those under the age of 10 years, 31\% among those 10-19 years old, and $30 \%$ among those 20-39 years old. As shown in Figure 1, the Sandi Yura cases showed a similar pattern, with $35 \%$ of them in the under-10 age group, $24 \%$ between 10 and 19 years old, and $31 \%$ between 20 and 39 years old.

In terms of gender, no significant differences were found either in the cases diagnosed by the DHNR $(54 \%$ were males) or in those diagnosed by Sandi Yura (49.2\% were males).

No gender and age data were available from the NCME.

\section{Malaria transmission and climate}

Figure 2 shows the total number of malaria cases reported by the three organizations in each month from January 1992 through December 1995, as well as the mean rainfall for each month. The monthly number of malaria
FIGURE 1. Percent of malaria infections by age group, diagnosed by two organizations in the Lower-Napo region of Ecuador, 1992-1995

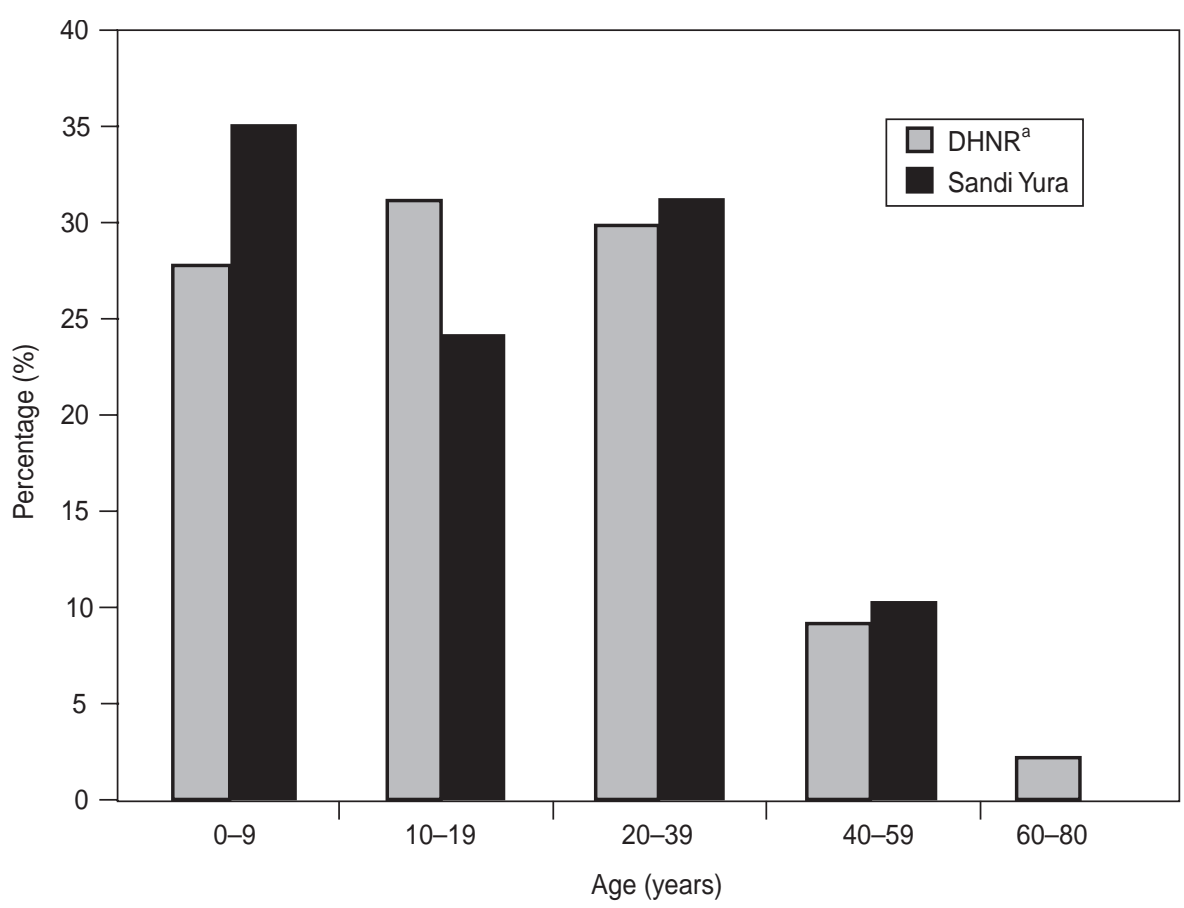

a DHNR = the district hospital in Nuevo Rocafuerte. casco vvas onsmas, cnepre ive ontans peaks in March, June, and October. Monthly rainfall did not correlate with the monthly incidence of malaria $(r=$ $0.24)$, nor did mean temperature $(r=$ $-0.33)$. This lack of association was also true when the Sandi Yura clinical cases were excluded.

\section{DISCUSSION}

The results of this study indicate that the Lower-Napo region is an area of
TABLE 1. Plasmodium vivax and $P$. falciparum malaria cases diagnosed by two organizations in the Lower-Napo region of Ecuador, 1992-1995

\begin{tabular}{lccccc}
\hline & \multicolumn{2}{c}{$\begin{array}{c}\text { Plasmodium } \\
\text { vivax }\end{array}$} & & \multicolumn{2}{c}{$\begin{array}{c}\text { Plasmodium } \\
\text { falciparum }\end{array}$} \\
\cline { 2 - 3 } \cline { 5 - 6 } & NCME $^{\mathrm{a}}$ & DHNR $^{\mathrm{b}}$ & & NCME & DHNR \\
\hline 1992 & 188 & 88 & & 22 & 2 \\
1993 & 152 & 38 & & 20 & 2 \\
1994 & 203 & 109 & & 17 & 18 \\
1995 & 169 & 213 & 2 & 15 \\
\hline
\end{tabular}

a NCME = National Center for Malaria Eradication, office in the town of Coca.

${ }^{b}$ DHNR $=$ the district hospital in Nuevo Rocafuerte.

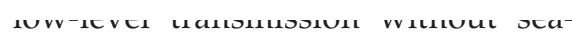
sonal variation. Collectively, the cases diagnosed by the DHNR, by Sandi Yura, and by NCME show that the overall malaria risk for the region is considerably higher than that suggested by NCME data alone. Since NCME resources are allocated on the basis of malaria risk, there is an urgent need for greater coordination among the health institutions working in the area in order to produce a more adequate picture of the malaria burden, as well as to strengthen future control efforts.

With an API of just 6.2, the NCME data would indicate that the LowerNapo region is a low-risk area. However, the much higher API figures (35-40) that this study also found would indicate the region is one of high risk. These results have major implications for NCME's nationwide allocation of resources since the NCME unit in the Lower-Napo region has received only limited support.

Another surprising finding came from comparing the DHNR API for the Aguarico canton with figures for other cantons in Ecuador. With an API of 40.4 , that would make Aguarico one 
FIGURE 2. Comparison of monthly mean rainfall and incidence of malaria cases, LowerNapo region of Ecuador, 1992-1995

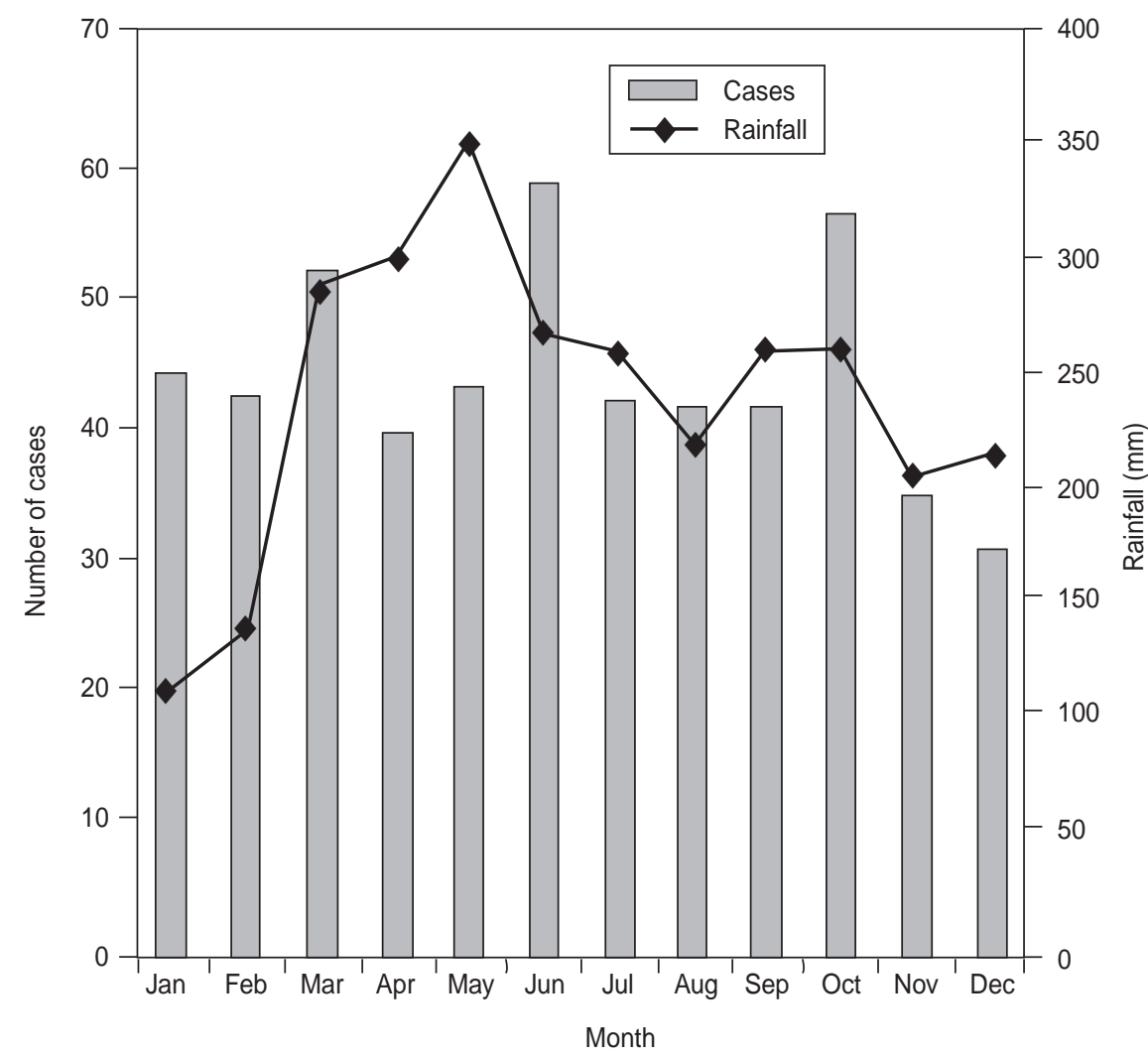

of the riskiest cantons in the country, exceeded only by two cantons in the Pacific coastal province of Esmeraldas, San Lorenzo (API of 86.6) and Eloy Alfaro (API of 46.3) (5).

Given that the geographic conditions are similar across the LowerNapo region, one might expect to find a higher malaria incidence diagnosed by the NCME unit in Coca because of the greater population density and migration rates in that area. Nevertheless, the lower diagnostic rates at the Coca institution might have been due to the small number of people who go to NCME-Coca for medical care and a decrease in NCME-Coca field activities due to difficulties that have included a shortage of drugs, financial problems, and labor disputes.

The increase in Plasmodium falciparum malaria cases in the DHNR in recent years is similar to a trend in the rest of the country (5). Data from the
NCME-Coca center showed an opposite trend, creating a false sense of security. Again, low utilization together with financial problems in the NCME unit could be responsible for this apparent contradiction.

So far, the proportion of $P$. falciparum cases in the Aguarico canton has remained relatively low $(2 \%-14 \%)$ compared to that found in the highest-risk cantons of the country (30\%-66\%) (5), and without the severe complications associated with $P$. falciparum malaria (4). However, it is important to be aware of the possibility of a chloroquine-resistant strain appearing in the Lower-Napo region.

The high proportion of malaria among children in the Lower-Napo region is likely related to the vector's behavior and indicates that transmission takes place indoors. Although P. vivax malaria is generally regarded as benign, it may produce considerable global mortality through malnutrition (8) and may be responsible for a large share of student absences from school (9). The fact that this study found no discernible difference in malaria incidence between the genders reinforces the hypothesis of indoor transmission; a higher incidence among males would have suggested outdoor transmission.

Research in other areas of the Amazon region has found that lower precipitation coincides with a higher incidence of malaria (10). Possible explanations for this phenomenon include the effect of higher temperatures on the development of the parasite in the mosquito (11) and the increase in the vector density related to manmade secondary larval breeding sites (12). However, we found no relationship in the Lower-Napo area between malaria incidence and either rainfall or temperature. This might be explained by the region's high level of precipitation throughout the year, which allows the constant formation of mosquito breeding sites. On the other hand, the high rainy season in the LowerNapo region might be too wet for the vectors to breed and allow maximal transmission to occur (13).

Detailed serological and entomological studies will be needed to confirm these findings and better understand malaria transmission in the LowerNapo region. This study highlights the need for closer coordination among the area's malaria-control organizations so as to gain a better understanding of local malaria epidemiology and to use that knowledge in designing and implementing effective control strategies.

Acknowledgements. We thank Mr. Toala (NCME-Coca) and Dr. Castro (NCME-Sucumbios) for allowing the collection of data from the NCME records. We also express our appreciation to the Ecuadorian Air Force and the Civil Aviation Agency for the meteorological data. This study was part of a primary health care program supported by Medicus Mundi Andalucía. 


\section{REFERENCES}

1. Roberts DR, Lauglin LL, Hsheih P, Legters LJ. DDT, global strategies, and malaria control crisis in South America. Emerg Inf Dis 1997;3(3):295-302

2. Kroeger A, Meyer R, Mancheno M, Gonzalez $M$. Health education for community-based malaria control: an intervention study in Ecuador, Colombia and Nicaragua. Trop Med Internat Health 1996;1(6):836-846.

3. Amunárriz, M. Salud y enfermedad: patología tropical en la región amazónica ecuatoriana. Pompeya, Ecuador: Cicame; 1984.

4. Amunárriz M. Paludismo, 20 años de historia. In: Cicame, ed. Estudio sobre patologías tropicales en la Amazonía ecuatoriana. Pompeya, Ecuador: Cicame; 1991. p. 9-26.

5. Narváez A, Ortiz P. Panorama epidemiológico de la malaria en Ecuador 1986-1993. Quito: Ministerio de Salud Pública del Ecuador; 1994. (Boletín epidemiológico 41).

6. World Health Organization. Implementation of the Global Malaria Control Strategy.
Geneva: WHO; 1993. (Technical Reports Series 839).

7. Fuerza Aérea Ecuatoriana. Datos meteorológicos 1992-1995 [mimeographed document]. Quito: FAE; 1996.

8. Williams TN, Maitland K, Phelps L, Bennett S, Peto TE, Viji J, et al. Plasmodium vivax: a cause of malnutrition in young children. QJM 1997;90(12):751-757.

9. Trape JF, Lefebvre-Zante E, Legros F, Druilhe $\mathrm{P}$, Rogier C, Bouganali $\mathrm{H}$, et al. Malaria morbidity among children exposed to low seasonal transmission in Dakar, Senegal and its implications for malaria control in tropical Africa. Am J Trop Med Hyg 1993;48(6):748-756.

10. Aranha Camargo LM, Urbano M, Krieger H, Plessman E, Pereira L. Unstable hypoendemic malaria in Rondonia (Western Amazon Region, Brazil): epidemic outbreaks and workassociated incidence in an agro-industrial rural settlement. Am J Trop Med Hyg 1994; 51(1):16-25.
11. Mota EGF. Fatores determinantes da situação da malária na Amazônia. Rev Soc Bras Med Trop 1992;25(Suppl 2):27-32.

12. Marques AC. Human migration and the spread of malaria in Brazil. Parasitol Today 1987;3:166-170.

13. Gonzalez JM, Olano V, Vergara J, ArevaloHerrera M, Carrasquilla G, Herrera S, et al. Unstable, low-level transmission of malaria on the Colombian Pacific Coast. Ann Trop Med Parasitol 1997;91(4):349-358.

Manuscript received on 5 April 1999. Revised version accepted for publication on 21 September 1999.

RESUMEN La malaria está reapareciendo en la mayoría de los países endémicos de América del Sur. En el Ecuador, la enfermedad es endémica en la costa del Pacífico, en los valles de los Andes y en la cuenca del río Amazonas. En el Bajo Napo en el nordeste del Ecuador, la malaria se consideraba eliminada en los años setenta, pero la enfermedad ha vuelto a aparecer en años recientes. Aunque en la actualidad tres organismos participan en actividades antimaláricas en esa zona, sus actividades no están coordinadas. Este estudio se efectuó con el propósito de describir la epidemiología de la incidencia de malaria en el Bajo Napo durante el período de enero de 1992 a diciembre de 1995, así como de determinar hasta qué punto existen patrones estacionales en la transmisión en ese territorio.

Para determinar la incidencia de malaria, se recogieron datos para el cuadrienio 1992-1995 a partir de los registros de los tres organismos con actividades antimaláricas: la sede del Servicio Nacional de Erradicación de la Malaria (SNEM) en Coca, el hospital de distrito de Nuevo Rocafuerte (HDNR) y una asociación de trabajadores de salud comunitarios llamada Sandi Yura. La información climatológica para el mismo período se obtuvo de la Fuerza Aérea Ecuatoriana y de las autoridades de aviación civil.

Durante el período de 1992 a 1995, el SNEM diagnosticó un total de 773 casos de malaria, el HDNR 485, y Sandi Yura 859. Para el mismo cuadrienio se detectó un índice parasitario anual de 40,4 con los datos del HDNR; 35,8 con los de Sandi Yura, y 6,2 con los del SNEM. Plasmodium vivax fue el parásito hallado con mayor frecuencia en el territorio ( $92 \%$ de todos los casos). De las personas infectadas, $28 \%$ tenían menos de 10 años de edad. No se hallaron diferencias patentes entre los sexos, ni tampoco variaciones estacionales del número de casos.

Es preciso hacer más investigaciones para confirmar estos resultados y para entender más a fondo la transmisión de la malaria en la zona. El estudio subraya la necesidad de fortalecer la coordinación entre las organizaciones que participan en la lucha antimalárica en el territorio, a fin de mejorar los conocimientos sobre la epidemiología de la malaria y de diseñar y poner en marcha estrategias de control adecuadas. 